\title{
Counter-hegemony of the East Java Biennale art community against the domination of hoax content reproduction
}

\section{Perlawanan hegemoni komunitas seni Biennale Jawa Timur terhadap dominasi reproduksi konten hoax}

\author{
Jokhanan Kristiyono $^{1 *}$, Rachmah Ida $^{2}$, \& Musta'in Mashud ${ }^{3}$
}

${ }^{1}$ Doctoral Program of Social Sciences, Faculty of Social and Political Sciences, Universitas Airlangga ${ }^{2}$ Department of Communication, Faculty of Social and Political Sciences, Universitas Airlangga ${ }^{3}$ Department of Sociology, Faculty of Social and Political Sciences, Universitas Airlangga Address: Jalan Dharmawangsa Dalam, Airlangga, Surabaya, East Java 60286

E-mail: jokhanan.kristiyono-2017@fisip.unair.ac.id

\begin{abstract}
This research analyses and describes in detail how the digital biennale activities that are a part of the Indonesian Digital arts community has become a form of criticism and silent resistance to the social hegemony. It refers to the ideology, norms, rules, and myths that exist in modern society in Indonesia, especially the reproduction of hoax content. Hoax refers to the logic people who live in a world of cyber media with all of its social implications. This phenomenon is a problem, and it is at the heart of the exploration of the art community in East Java Biennale. The critical social theory perspective of Gramsci's theory forms the basis of this research analysis. The qualitative research approach used a digital ethnomethodology research method focused on the online and offline social movements in the Biennale Art Community. The data collection techniques used were observation and non-active participation in the process of reproduction-related to the exhibition of Indonesian Biennale digital artworks. It was then analyzed using Gramsci's hegemony theory. The purpose of this study was to describe the process of social movements in a digital format conducted by the Indonesian Biennale when reproducing works of art to counteract the dominance and hegemony of the Hoax phenomenon in Indonesia. The benefit of this research was that it obtained a preposition of Gramsci's hegemony theory in the world of digital art as created by contemporary Indonesian Biennale artists. Digital technology has had a tremendous effect on the media industry, government, trade, informal industry sector, human resources, urban planning, services, disaster relief, health, education, religion, artistic and cultural expression, in addition to various other fields. The conclusion obtained from this research is that there is a formation of a new hegemony, a digital hegemony. This new hegemony is of particular concern for the digital artists in East Java Biennale. Through the digital format works, the artists also try to communicate their art as a form of silent resistance, protest, and criticism of the hegemony that occurs in society, referring to the ideology, norms, and myths. It can be called a digital counter-hegemony.
\end{abstract}

Keywords: East Java Biennale; art communities; social hegemony; hoax; counter-hegemony

\begin{abstract}
Abstrak
Penelitian ini menganalisis dan mendeskripsikan secara rinci tentang bagaimana kegiatan biennale digital yang merupakan bagian dari omunitas Seni Digital Indonesia dan menjadi sebuah bentuk kritik serta perlawanan diam-diam terhadap penguasa sosial. Hal ini merujuk kepada ideologi, norma, aturan, dan mitos yang ada pada masyarakat modern di Indonesia, khususnya para pembuat konten Hoax. Hoax mengacu kepada logika masyarakat yang tinggal di dunia maya dengan segala implikasi sosialnya. Fenomena ini merupakan sebuah masalah dan hal ini merupakan jantung eksplorasi dari komunitas seni di Biennale Jawa Timur. Perspekif teori kritik sosial oleh Gramsci merupakan bentuk teori dasar dari analisis penelitian ini. Penelitian dengan pendekatan kualitatif ini menggunakan sebuah metode penelitian etnometodologi digital yang berfokus pada pergerakan sosial secara daring dan luring dalam Komunitas Seni Biennale. Teknik pengumpulan data yang digunakan adalah observasi dan partisipasi pasif dalam proses menghasilkan yang berkaitan dengan pameran karya seni digital Biennale Indonesia. Kemudian hal ini dianalisis dengan teori hegemoni Gramsci. Tujuan penelitian ini adalah untuk mendeskripsikan proses pergerakan sosial dalam format digital yang diadakan oleh Biennale Indonesia pada saat memproduksi karya seni untuk menetralkan dominasi dan hegemoni fenomena Hoax di Indonesia. Manfaat dari penelitian ini adalah untuk memperoleh sebuah proposisi dari
\end{abstract}


teori Hegemoni Gramsci dalam dunia seni digital yang diciptakan oleh pegiat seni moderen di Biennale Indonesia. Teknologi digital telah mempunyai efek yang dahsyat dalam perindustrian media, pemerintahan, perdagangan, sektor industri informal, sumber daya manusia, tata rencana kota, pelayanan, bantuan bencana, kesehatan, pendidikan, agama, ekspresi seni dan budaya sebagai tambahan dalam berbagai bidang. Studi ini menyimpulkan bahwa terdapat sebuah bentuk dari sebuah hegemoni baru, sebuah hegemoni digital. Hegemoni baru ini adalah sebagian kesadaran untuk para pegiat seni digital di Biennale Jawa Timur. Melalui karya seni digital, para seniman juga juga berusaha untuk mengkomunikasikan seni mereka sebagai sebuah bentuk perlawanan diam-diam, protes dan kritik terhadap hegemoni yang terjadi di masyarakat yang merujuk pada ideologi, norma-norma, dan kepercayaan. Hal ini dapat disebut sebagai penghitung hegemoni digital.

Kata kunci: Biennale Jawa Timur; komunitas seni; hegemoni sosial; hoax; perlawanan hegemoni

\section{Introduction}

This social phenomenon is interesting to study because the digital activities carried out by digital artists are social movements or digital movements in the form of art exhibitions aimed to show the public and the world their protests related to the dominance of the world, the state and the community reality (counter-hegemony). This form of criticism by digital artists is a silent resistance to the ideology, norms, rules, and myths that exist in society, especially in modern Indonesian society, which are always connected on the Internet. This hegemony over the ideology or beliefs of social society refers to the critical social theory of Marxism in Gramsci's mind and perspective. As written in the Interface Journal 2010 Vol 2 on Community Crisis, the Social Movement is used to fight the hegemony and domination in society. The research conducted by Carrol in 2010 saw that modern humans in the $21^{\text {st }}$ century rely heavily on creating counter-hegemonic historical boxes in their social practices and visions. It is a modern society capable of forming and developing post-capitalist economic democracies. The organic crisis of neoliberal capitalism and how the ecological crisis deepened is making breakthroughs and resisting hegemony. Capitalist practices that dominate in social society became Caroll's main idea when analyzing the social movements of modern society using Gramscian theory. This complements the analytical and strategic lens of the researchers (Carroll 2010).

Nowadays, the growth of the digital world will not be separated from the social reality of society concerning the elements of work, culture and the social interactions with the economic, political and socio-cultural perspectives. Digital technology has had a tremendous effect on the media industry, government, trade, informal industry sector, human resources, urban planning, services, disaster relief, health, education, religion, artistic and cultural expression in various fields. In addition to providing positive effects, digital technology also has negative effects that are no less large, such as being able to strengthen or produce new forms of supervision from the authorities, political manipulation and emphasis, commercialization and socio-religious effects. The effects of digital technology lead to the expansion and improvement of the available forms of connectivity. This also leads to different forms of misinformation, miscommunication and the negative effects caused by dramatic and sometimes fatal socio-cultural life.

The new form of hegemony or digital hegemony is of concern related to the activities of digital artists in Indonesia, especially the domination and publication of the Hoax content in modern society. Biennale, as a digital art community with a digital format, works to try to communicate their art as a form of silent resistance, protest and criticism of the hegemony that occurs in society. This includes ideology (ex. politics), the norms and the myths used to carry out social movements in the form of digital activities that conduct a "silent protest" against the hegemony created by the development of digital communication technology itself. This can be referred to as a Digital Counter- Hegemony. The "silent protest" activity carried out by the East Java digital artist community is done by conducting an exhibition of Biennale digital artworks. This has been going on since 2003. It continues to actively conduct exhibitions every two years. East Java Biennale held an exhibition of digital arts as East Java Biennale \#7 on October 9-22, 2017. In this exhibition, 27 digital artworks by 24 digital artists in Indonesia were exhibited at the biennale seven exhibition. 
Researchers made preliminary observations at the seventh biennale exhibition in East Java in October 2017 that had the theme "World is Hoax". There were 27 digital artworks exhibited showing criticism of the ideology such as the example of a work by Benny Wicaksono titled "Banality in Mechanism Movements". The PKI G30S film gave birth to its trauma for this artist. This film is so terrible and "banal", it is interpreted very roughly. What is interesting here is that Benny Wicaksono is a digital artist trying to show his criticism of the ideological hegemony implanted by the government, especially the new order, in the form of digital art. This artwork not only shows its criticism visually but its digital audio was measured on an audiometer that has become the main identity. This digital artwork tries to show the public that the depiction of horror and darkness in the film is not only visual but also through audio. In addition to Benny's digital art that criticizes the forms of ideological hegemony, other works of art criticize the hegemony of the myths in Indonesian society. These digital artworks show the practices of digital technology and how these digital practices give birth to or develop specific forms of individual and group identity.

The environment and life of modern society is shaped by the trends present in globalization and the conflicting identities therein (Naz, Khan, Daraz, \& Hussain 2012). The information technology revolution and the restructuring of capitalism has created a new form of society, namely network society. This is marked by the globalization of the economic activities that are determined strategically according to the forms of organizational network present. A culture of true virtuality is built by a broad, interrelated and diverse media system. New social organizations were formed in the modern era, in its broad globality, and spread throughout the world. This global social organization became industrial capitalism in the 21st century, moving to shake institutions to change the culture itself (Ahmad et al. 2019). The organization creates wealth and drives poverty. This is in addition to spurring greed, innovation and hope while creating difficulties and instilling despair in the world community. It is easy to agree on the fact that all identities are built from a sociological perspective. The real problems are how, from what, by whom and for what. The construction of identity uses basic material from history, geography, biology, institutions of production and reproduction, from collective memories and personal fantasies and from the apparatus of power and religion (Castells 2010).

Changes in communication and information technology have been fast until the emergence of transitional social life upheaval. Artwork and art performances experience new disturbances and threats, especially from within communal groups drawn from religion, ethnicity and certain groups where there are forms of cultural domination and the determination of the middle currents that occur in Indonesia (Ida 2015). The development of fine arts and performing arts in Indonesia has experienced significant developments, especially with the support of communication and information technology. Art shows and digital art exhibitions continue to grow. Young artists within the fields of performing arts and fine arts in areas such as Surabaya have begun to build visual arts communities. These visual artists build and form communities because they have a common interest, namely video art, performing arts and electronic-based music. Surabaya's new media arts center was formed in 2007. The community regularly meets to discuss and share their productions.

Mainstream culture continues to develop and dominate in the development of art in Indonesia, through art, paintings, film, music and other channels. The dominance of this middle stream culture has become a phenomenon of the hegemony that is fought for by the Indonesian digital art community. By continuing to carry out digital social movements (offline-online movements) and creating digital artworks as a form of silent resistance, they exhibit digital works of art to show other people this resistance (Tufekci 2014). The counter-hegemony conducted by the digital art community in Indonesia is a digital social movement (digital activism) used to fight the ideas of the mainstream culture. The digital artworks exhibited by this community are expressions and aspirations that are a form of resistance to the domination and determination that occurs in modern and contemporary society today.

The modernity that occurs at this time in the information society, especially for artists, can be characterized as an attitude that backs cultural traditions, collectivity and the continuous prioritization of technology and individualism (Murray, 2006). The modern art that occurs in Indonesia shows 
there to be development in two opposing directions. First, modern art is totally and deliberately not based on tradition or culture. This modern art is created through an exogenous process. Second, modern art makes cultural traditions a reference for the creation of modern artwork. This modern art is constructed through an endogenous process (Chalmers 2006, Cohen 2016).

The development of fine arts in Indonesia is inseparable from the development of Western art, especially in Europe. The Dutch colonial period brought European fine arts (sculpture and painting) to Indonesia. Paintings and sculptures from Europe also provide the basis for the development of modern art in Indonesia. European art believes in a single pathway for the advancement of modern art, known as 'the mainstream'. This single mainstream path that spread throughout the world coincided with the era of European colonialism in East Asia, including in Indonesia. Modernity in Western art grew and developed as a reaction to the bourgeoisie. This is why modern artists create works and try to make a difference in the art practices of the community. They alienate art praxis from the public (Djatiprambudi 2005).

The digital art communities in Indonesia continue to grow and move. One example is the Forum Lenteng with its digital art platform, namely senimedia.id. This community engages in digital forms of art activities by becoming a pioneer in the collective movements of the digital artist community in Indonesia. The community of digital artists who continue to produce technology-based works of art to communicate to the public is a collective movement that uses the senimedia.id platform. Artworks that show resistance to the social conditions of society show resistance to mainstream contemporary art.

Seeing the social phenomena as explained above, the hegemony and counter-hegemony problems within the Gramsci analysis are not quite deep enough to be able to examine digital-based social phenomena, especially the analysis of hegemony resistance movements conducted by the art community within the social movements collectives. This study provides a preposition and the development of Counter-Hegemony Gramsci analysis theory (Kumar 2011). The hegemony initiated by Gramsci started from the hegemony of power in the western world (Europe). This is as the theories about the domination and resistance movements based on European culture are very different from the conditions and Eastern cultures like in Indonesia. Collective movements in resisting European culture begin and become large because of the individual factors of the leader figure. The culture in Indonesia is a collective social movement based on cooperation and the consensus culture. There is a big difference in the basis of Western collective social movements with those in Indonesia. The digital activities and resistance movements carried out by the biennale digital art community and Forum Lenteng using digital platforms are the subjects of this research.

\section{Research Method}

This research uses ethnographic research methods, especially digital ethnographies. This is done by using data collection techniques and engaging in non-active participation (Pink et al. 2015). This research studies in-depth (grounded research) the process of the digital social movement (digital activism) of the East Java Biennale as a digital art community used to produce digital art and to exhibit their artworks. Digital ethnomethodology was used as the chosen research method. The researcher observed passive participation in the production process of the digital communication within the digital artworks of the Indonesian digital artists, namely the digital art community of East Java Biennale. The researchers sought to analyze and describe the digital counter-hegemony that occurs in the digital art community. The purpose and benefits of this research are to get a preposition of Gramsci's hegemony theory on the information society in Indonesia, especially the Indonesian digital art community that uses digital communication media when conducting social interactions (Achmad \& Ida 2019).

\section{Results and Discussion}

The Indonesian Biennale develops and moves socially (social movements) in big cities in Indonesia. Besides Jakarta, the biennale movement was also developed in the cities of Yogyakarta, Surabaya (in this case, East Java), Makassar, Bali, and Bandung. The identity is used to describe the city or region, namely Jogja Biennale, East Java Biennale, Makassar Biennale, Bali Biennale and Bandung 
Biennale. Biennale Jogja is a consistent major art event in Indonesia. The holding of routine activities every two years in the Biennale Jogja is massive. The history of the activity can be traced since the first time it was held in 1988 in Yogyakarta. The series of Biennale Jogja exhibitions had an impact on the emergence of artists, works and discourses that coloured the development of contemporary art in Indonesia, especially Yogyakarta.

The development of the Biennale in Indonesia cannot be separated from its existence in following the development of technology and communication. The works created by digital artists who are members of the Indonesian Biennale are not immune to expressions of the social, cultural and political conditions that have been happening in the community. The more innovative the work, the higher the technology used. The availability of features in the new platform provides new facilities for art workers (digital artists) to create an opportunity to promote their work. Technology-based arts is a basic concept and this is the mind-set of today's digital artists. The art produced is not only a platform or digital format. The process of creating works of art with the concept of digital thought as a form of appreciation by these artists becomes the basis in the creation of digital artworks. Today, digital is not just a media format or a physical form of technology such as material elements, measurements and other technical data. Digital is the rationale for today's modern society, its ways of thinking and acting in order to interact (Castells 2010).

In information and communication technology, they can massively progress and cause an upheaval in the transitioning social-political life in Indonesia. The art and art performances themselves experience "new threats" especially from mass (communal) groups in the name of religion, ethnicity and certain groups. "Communal censorship" which is a new threat to works of art and art performances in the country, has not only become a new repressive movement. It has also become a terrible 'new mass power' model because it has become viral on social media whose use is extraordinary. It has passed through unilateral policies successfully only because of pressures 'on behalf of the public' concerning works of art and art performances. The Indonesian culture is very diverse, culturally and ethnically, with various languages. This has become a dynamic uniqueness in the development of the technological culture of Indonesia. The connectivity of the diversity in Indonesia can create technology-based artwork that is very different from that of other nations. Hacktivism is a technical term related to hacking or damaging technology works. This Digital Art activity is carried out by digital artists in Indonesia in the process of creating digital artworks (Jurriëns 2017).

The development of the digital world will not be separated from the social reality of society and the elements of work, culture, social interaction within economic, political and socio-cultural perspectives. Digital technology has had a tremendous effect on the media industry, government, trade, the informal industry sector, human resources, urban planning, services, disaster relief, health, education, religion, artistic and cultural expression in relation to various other fields. In addition to providing positive effects, digital technology also has negative effects that are no less large, such as being able to strengthen or produce new forms of supervision from the authorities, political manipulation, emphasis, commercialization and socio-religion which can be called Digital Hegemony. This new hegemony is in a digital format.

The scientific article titled "Turning The Tide: The Oppositional Past and Uncertain Future of The Contemporary Biennial" by Rafal Niemojewski, appeared in the Seismopolite Journal Vol. 6 in 2013. The idea of Biennale's contemporary art as a suitable space for political activism in real life requires a lot of imagination from the people who frequently visit large-scale recurring exhibitions throughout the world at established exhibitions. This can include, for example, the Venice Biennale. The history of the modern Biennale changes unexpectedly and in a short period, it begins to foster a rhetoric of bold resistance against the structure of power and institutionalized inequality (Niemojewski 2010).

The new generation of the Biennale community was born from a global context with political activism inherent in each of its projects. During that period, new Biennales emerged in areas that are largely peripheral and interrupted in connection with the core of the contemporary art world, which at that time was still centred and revolved around several capitals of Western art that were 
empowered throughout modernity. Introduced in what was later designated the Third World, this could be translated as being geographically remote, and politically and economically incompatible with the West. One thing that these institutions have is their real desire to challenge the status quo of the unequal power relations in the art world and the world at large. The early edition of Havana Biennial arguably articulates this effort explicitly (Niemojewski 2018).

One of the most distinctive features of the current discussion of placing politics in the arts and its exhibition is the suspicion and rejection of any large-scale political change strategy. The alternative to macro politics is the tendency for local politics. Localism in several different forms is present in many contemporary art discourses with ideas about the realities of direct experience, antiglobalization, the self-government community and others. The notion of 'community' itself, standing apart from the alienation of individuals and the state of totalization, has long been a principle in the art of criticism. The second concept in art and political discussion, which has an equal impact on understanding current practice, is organized around a strong commitment to an ideal model of political practice which is almost always participatory. It connects the participants in a "dialogical community" and empowers the constituencies, whose rights are revoked, silenced and excluded by the dominant discourse.

The difference between this dissertation research and the research conducted by Niemojewski in 2009 , published in the 2013 Seismopolite journal vol 6, is related to the order of more micro-research subjects, namely the art community that carries out production processes and organizing digital art exhibitions. The art exhibitions examined in this dissertation are not only focused on the Biennale activities but also on other digital art exhibition activities in Indonesia conducted by Indonesian art communities. The hegemonic resistance analysis carried out by the community was almost the same as that studied by Niemojewski. However, the purpose was different. This dissertation aims to find the prepositions of hegemony theory, specifically Digital Counter-Hegemony. Other research into the art and social movement is Katherine Bruhn's scientific article titled "Art and Social Engagement in Yogyakarta, Indonesia: Ketjilber moving and the Legacy of Rice Canines". It was published in the Seismopolite Journal Vol. 13 Year 2015. Bruhn researched two art communities in Indonesia, namely Ketjilber Moving and Taring Padi. In 2010, the Taring Padi Community helped the people of Sidoarjo commemorate the fourth anniversary of the Lapindo Mud disaster. Taring Padi, a political art group from Yogyakarta, Central Java, joined the Sidoarjo community for a four-day cooperation project in May 2010. The activity was known as "Reflection in the Mud". This project focused on reviving the collective memory of the people of Sidoarjo.

The activity of the Sidoarjo people placed dolls, banners and masks into the mud. These objects are intended to symbolize the oppressors who have robbed them of their livelihoods, voices and the history of their population. The parade ended with a carnival and a concert where residents and artists alike sang together, expressing their dissatisfaction and continuing concerns for the future of those affected by disaster and corruption. Taring Padi's work within the Sidoarjo community is an example of this group's involvement with the local communities in both Indonesia and abroad (Bruhn 2013).

The argument that modern Indonesian artists are "socially involved" is not new. While groups such as Taring Padi reflect the involvement of contemporary artists with the Indonesian people or people, a similar interest can be found among the first modern artists in Indonesia. Beginning in the 1930s with individual works including those by Sudjojono, Affandi, and Hendra Gunawan, an art ideology emerged that emphasizes people's awareness. Art historian Caroline Turner described how these artists, who are considered to be the fathers of Indonesian modern art, "emphasize art that adheres to a vision of freedom that encompasses all walks of life". Organized collectively around the artists' workshops, these artists fight for their style. This is described as "socially-involved realism" (Turner 2005).

\section{Gramsci's hegemony criticism: Digital art work of the Indonesian art community}

The East Java Biennale \#7 Exhibition was held in October 2017 with the theme "World is Hoax". The exhibition showed 27 digital artworks from Indonesian digital artists. One of the artists, Benny Wicaksono, exhibited his digital artwork. Benny Wicaksono's digital work entitled "Banalitas" in 
the form of the PKI G30S hacktivism showed a clear criticism of ideology such as the work of the Mechanical Movement. The audio produced in the PKI G30S Film gave birth to its own trauma. This film is so terrible and "banal." It is interpreted very roughly. Benny Wicaksono, as a digital artist, is trying to show criticism of the ideological hegemony implanted by the government, especially the new order, in the form of digital art. This artwork is not only visual. The digital audio measured on an audiometer becomes the main identity.

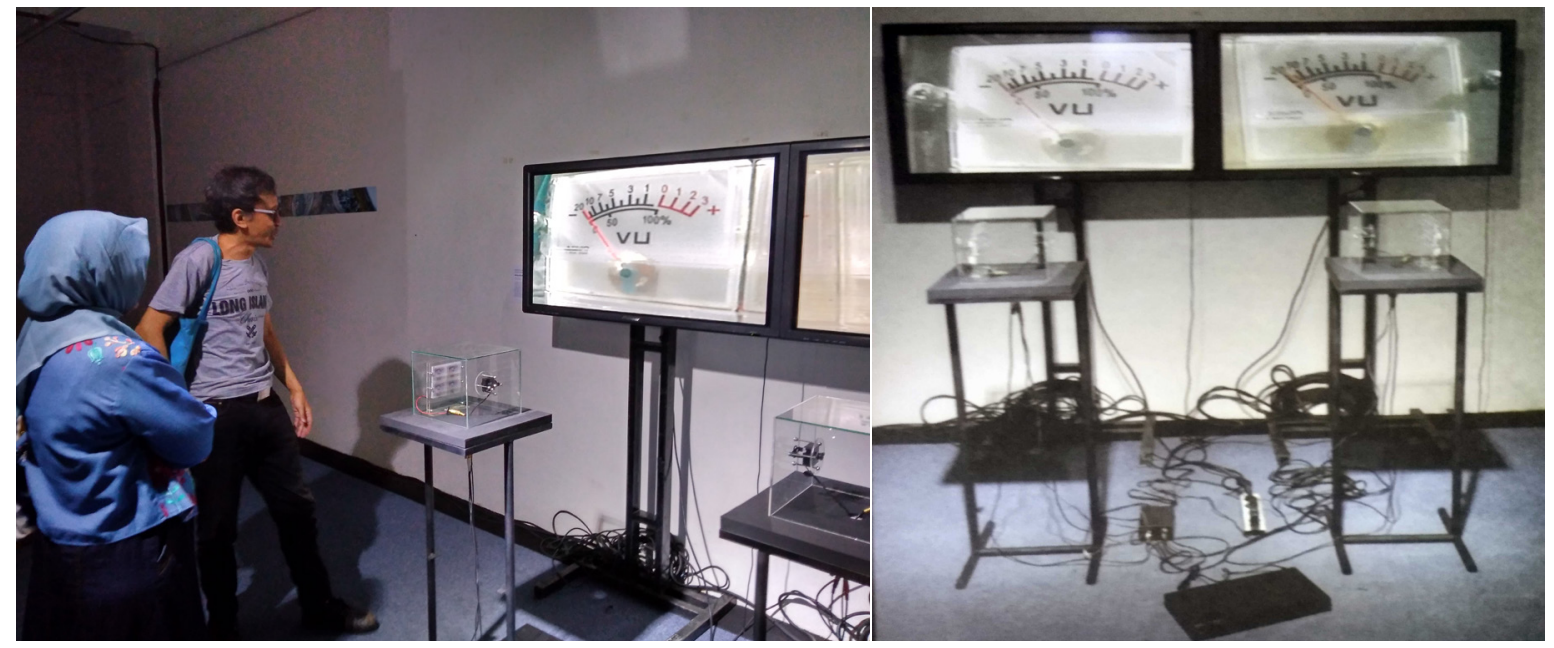

Figure 1.

Digital artwork installation "Banality in Mechanism Movements" by Benny Wicasono

(Source: Researcher)

This digital artwork tries to show the public that the depiction of horror and darkness in the film is not only visual but that it is also done through the audio. In addition to Benny's digital art that criticizes the forms of ideological hegemony, other works of art criticize the hegemony of the myths that exist in Indonesian society. These digital artworks show the practices of digital technology and how these digital practices give birth to or develop specific forms of individual and group identity. The G30S/ PKI film gave birth to its own trauma for the artist Benny Wicaksono. This film is scary and banal for this artist. This film is a human tragedy, although up until now it is still a debate over who is right and who is wrong. The artwork titled "Banality in Mechanical Movements" was shown at the East Java Biennale \#7 exhibition, turning the sound in the film into a mechanical movement. This film was changed into something fun and boring to watch again. Being fun but boring is better than enjoying something terrible.

This work of art seems to distort the mindset of the audiences who believe that the G30S/PKI events are terrible without ever imagining or fantasizing from other perspectives to reduce the trauma. The tragedy was changed to something artsy with an artistic background. This artwork is based on modified analog audio machine repairs. Benny Wicaksono's work is one of the media artworks that is both a manifestation and a tension of the creative energy in the context of cultural discourse. The advancement of the digital world will not be separated from the social reality of society, especially in the context of work and the social interactions with the economy, political and socio-cultural perspectives. Digital technology has had a tremendous affect on the media industry, government, trade, informal industry sector, human resources, urban planning, services, disaster relief, health, education, religion, artistic and cultural expression as well as other fields (Jurriëns \& Tapsell 2018). In addition to providing positive effects, digital technology also has negative effects that are no less large, such as being able to strengthen or produce new forms of supervision from the authorities, political manipulation, and emphasis, commercialization and socio-religious damage. This can also be called a digital hegemony, which is a new hegemony in digital format. With information and communication technology growing rapidly, the bad side of digital technology is emerging, namely the form of supervision from the authorities (economic, social,and political). The manipulation of social reality in a digital format is increasingly rampant with the existence of incorrect information (hoax) created for political, commercial and social-cultural purposes. 


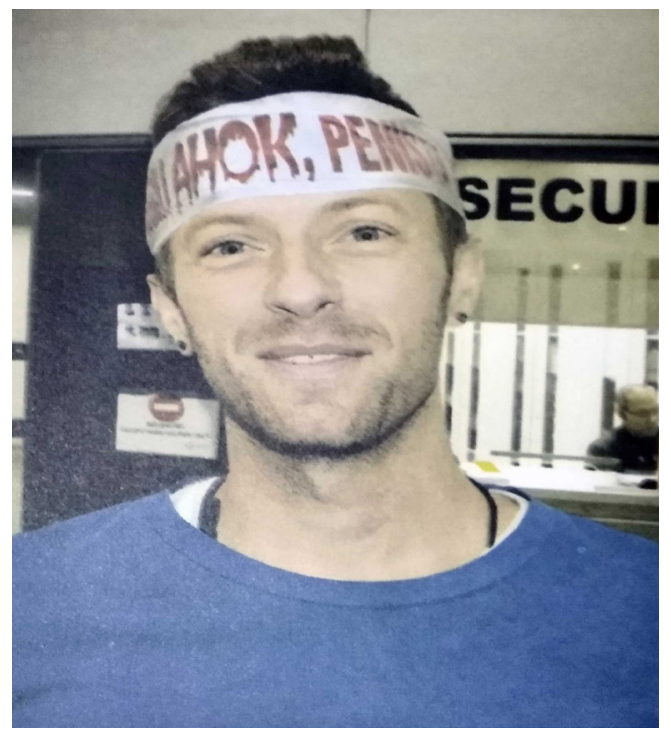

Figure 2.

Digital imaging \#Coldplay by Agan Harahap (Source: Biennale East Java \#7 Catalog)

Digital technology gives rise to increased forms of connectivity. It can also lead to forms of information error inclusive of miscommunication and the negative effects caused by dramatic and sometimes fatal socio-cultural life. The art and cultural expression of artists in Indonesia is also no exception as it is a social community that is actively involved in the effects of digital technology in Indonesia. The new form of hegemony, Digital hegemony, is of particular concern when it is related to the activities of the digital artists of the East Java Biennale. Through digital format works, these artists try to communicate their art as a form of silent resistance, protest and criticism of the hegemony that occurs in society. They are against the ideology, norms and myths and they seek to make movements and social activities in the form of digital activities in order to conduct "silent protests" against the hegemony created by the development of digital communication technology itself. This can be called a digital counter-hegemony. The "silent protest" activity carried out by the East Java digital artist community also includes conducting an exhibition of biennale digital artworks. This has been going on since 2003 and it continues to actively conduct exhibitions every two years.

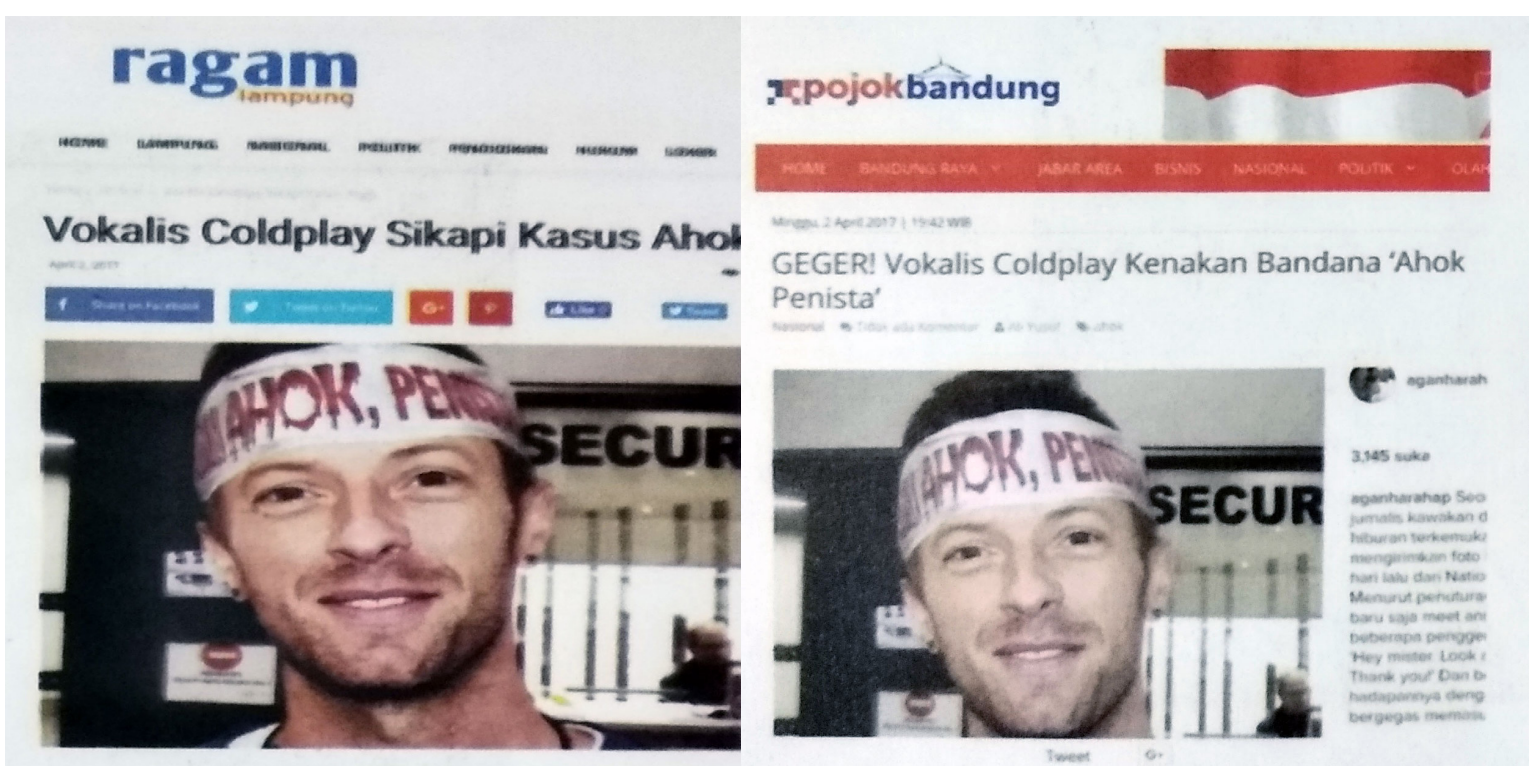

Figure 3.

Examples of a news hoax from news portals that use digital imaging \#ColdPlay by Agan Harahap (Source: Biennale East Java \#7 Catalog) 
Another digital artwork that was analyzed was the digital imaging of the artist Agan Harahap. The artist, whose full name is Yohanes Paganda Halasan Harahap, is an illustrator and photographer as well as a digital imaging artist. Digital imaging artworks are created and uploaded on the internet with the intention of making the citizens or netizens excited and going viral. One of the images is a photo of a singer from the international band Coldplay who used a bandana or headband with Ahok, Penista's writing on it. The edited photo became viral and this was exciting because it was used by various news portals and media platform alongside news headlines, it was hoax news (Fig.1).

Agan Harahap presented a compilation video of his viral photographic engineering work on social media at the East Java Biennale \#7 in 2017. The compilation of digital imaging works and their associated reporting was titled "Digital Clippings". This compilation video contains five series' of digital imaging artworks, namely Coldplay, Demo 98, Lohan PKI, Greetings and Hope. This compilation video is concrete evidence of the fact that fiction and the differences are so thin to the point that they are ambiguous in the current era of digital information. Mass media and social media are legitimate institutions for spreading false information and for celebrating hoaxes for the sake of interest.

\section{Conclusion}

The effects of digital technology have to lead to the expansion and improvement of forms of connectivity, leading to information errors, communication errors, and miscommunication, and the adverse effects caused by the dramatic and sometimes fatal socio-cultural life. The art and cultural expression of artists in Indonesia is no exception, as it is a social community that experiences what it is like to be actively involved in the effects of digital technology in Indonesia. With information and communication technology multiplying, the wrong side of digital technology is emerging, namely in the form of supervision from the authorities (economic, social, and political). The manipulation of the social reality in a digital format is increasingly rampant with the existence of incorrect information (Hoax) for political, commercial, and social-cultural purposes. This new form of hegemony is of particular concern when it is related to the activities of digital artists in the East Java Biennale. Through their digital format works, these artists try to communicate their art as a form of silent resistance, protest, and criticism of the hegemony that occurs in society, such as the ideology, norms, and myths used to conduct social movements in the form of digital activities. They seek to conduct "silent protests" against the hegemony created by the development of digital communication technology itself, which is called a Digital Counter-Hegemony. The "silent protest" activity carried out by the East Java digital artist community includes holding an exhibition of the Biennale digital artworks that have been ongoing since 2003. They continue to conduct exhibitions every two years actively. This form of criticism by digital artists is a silent resistance to the ideology, norms, rules, and myths that exist in society, uniquely modern Indonesian society, which always connected to the Internet. The media has become a medium forming and conveying reality. Will we still see this reality as mediated by the mass media and digital technology as truth? Digital art shows that "the world is a hoax".

\section{References}

Achmad ZA \& Ida R (2019) The shifting role of the listeners in the mediamorphosis process of culture radio: A case study of Jodhipati 106.1 FM. Masyarakat, Kebudayaan dan Politik 32 (3):240-250. http://doi.org/10.20473/mkp.V32I32019.240-250.

Ahmad A, Mahmood QK, Saud M, \& Mas'udah S (2019) Women in democracy: The political participation of women. Masyarakat, Kebudayaan dan Politik 32 (2):114-122. http://doi. org/10.20473/mkp.V32I22019.114-122.

Bruhn KL (2013) Art and Youth Culture of the Post-Reformasi Era: Social Engagement, Alternative Expression, and the Public Sphere in Yogyakarta. Ohio University.

Bruhn K (2015). Art and social engagement in Yogyakarta, Indonesia: Ketjilber moving and the legacy of rice canines. Seismopolite Journal of Art \& Politics 13. 
Carroll WK (2010) Crisis, movements, counter-hegemony: In search of the new. Interface 2 (2):168-198.

Castells M (2010) The power of identity. The Information Age Economy Society and Culture. https:// doi.org/10.1002/9781444318234.

Chalmers I (2006) Indonesia: An Introduction to Contemporary Traditions. Oxford: University Press Oxford.

Cohen MI (2016) Inventing the Performing Arts: Modernity and Tradition in Colonial Indonesia. University of Hawai'i Press.

Djatiprambudi D (2005) Pembentukan seni rupa modern di Asia Tenggara. Jurnal Seni Rupa FBS Unimed 2 (01):15-26.

Hepp A (2013) The communicative figurations of mediatized worlds: Mediatization research in times of the "mediation of everything. European Journal of Communication 28 (6):615-629. https://doi.org/10.1177/0267323113501148.

Ida R (2015) Imagining community in contemporary Surabaya. In: Hatley B (eds). Performing Contemporary Indonesia. Celebrating Identity, Constructing Community. Leiden, The Netherlands: Brill. 83-97. https://doi.org/10.1163/9789004284937.

JurriënsE(2017)Digital art:Hacktivismand SocialEngagement.In: JurriensE \& Tapsell R(eds). Digital Indonesia: Connectivity and Divergence. Singapore: ISEAS-Yusof Ishak Institute. 207-224.

Jurriëns E \& Tapsell R (2018) Challenges and Opportunities of the Digital 'Revolution' in Indonesia. In: Jurriens E (ed). Digital Indonesia. Connectivity and Divergence. Singapore: ISEASYusof Ishak Institute Singapore. 1-18. https://doi.org/10.1355/9789814786003.

Kumar S (2011) The exercise of hegemony in contemporary culture and media, and the need for a counter-hegemony initiative. Social Scientist 39 (11/12):33. www.jstor.org/stable/23076330.

McCafferty D (2011) Activism vs slacktivism. Communications of the ACM 54 (12):17-19. https:// doi.org/10.1145/2043174.2043182.

Murray S (2006) New Media Anxiety: Art History and the Problem of Modern Technology. Dissertation, Cornell University Graduate School.

Naz A, Khan W, Daraz U, \& Hussain M (2012) The crises of identity: Globalization and its impacts on socio-cultural and psychological identity among Pakhtuns of Khyber Pakhtunkhwa Pakistan. International Journal of Academic Research in Business and Social Sciences 1 (1).

Niemojewski R (2010) The Rise of the Contemporary Biennial 1984-2009. London: Royal College of Art.

Niemojewski R (2013). Turning the tide: The oppositional past and uncertain future of the contemporary Biennial. Seismopolite Journal of Art \& Politics 6.

Niemojewski R (2018) Contemporary art Biennials: Decline or resurgence? Cultural politics 14 (1).

Pink S, Horst H, Postill J, Hjorth L, Lewis T, \& Tacchi J (2015) Digital Ethnography: Principles and Practices. Los Angeles, United States: Sage Publications Limited.

Tufekci Z (2014) Social movements and governments in the digital age: Evaluating a complex landscape. Journal of International Affairs, 68 (1). 